INTERNATIONAL JOURNAL OF

SYSTEMATIC BACTERIOLOGY

Vo1. 20, No. 4 October 1970

pp. $425-433$

Copyright 1970, Iowa State University Press

\title{
THE DISTRIBUTION OF DIAMINO ACIDS IN CELL WALLS AND ITS SIGNIFICANCE IN BACTERIAL TAXONOMY
}

\author{
Elizabeth Work \\ Department of Biochemistry \\ Imperial College of Science and Technology \\ London, S. W.7
}

\begin{abstract}
The distribution of diamino acids in cell walls of bacterial species bears some relation totaxonomy. The most widely distributed diamino acid is meso-diaminopimelic acid which is present in probably all Gram-negative species and in numerous othergenera. L-lysine, also fairly common, is present in most Gram-positive cocci and in certain other species. Less frequent are DD or LL-diaminopimelic, $\beta-O H-d i a m i n o-$ pimelic, D or L ornithine, D or L diaminobutyric. The positions of these bifunctional amino acids in mucopeptides (glycopeptides), the cross linked polymers of the walls, are described. Mucopeptides are divided into two types according to the site of termination of the cross-link from the D-alanine of an adjacent peptide chain. In type D, the site is the diamino acid which is located in the main peptide chain; in type G (less common) the site is the D-glutamic acid, and the diamino acid is in the cross link. Other differentiating features of types D and G include the optical configuration of the diamino acid, and the nature of the amino acid linking the peptide chain to the hexosamine backbone.
\end{abstract}

Knowledge of the role of diamino acids in bacterial cell walls started with the finding by Salton (1953) of diaminopimelic acid (DAP) in walls of Bacillus subtilis, Escherichia coli and Salmonella pullorum and of limited amino acids, including lysine, in walls of Micrococcus lysodeikticus and Sarcina lutea. The presence of DAP had already been demonstrated in whole cells of many species of Eubacteriales and other organisms (Work 1951; Work and Dewey 1953) but it had not been found in the Gram-positive cocci. This early work had suggested that the distribution of DAP might have some taxonomic significance, especially when we found it in the bluegreen algae but not in any microorganism unrelated to bacteria. The subsequent very extensive studies of Cummins and Harris $(1956,1958)$ on walls of many species of Eubacteriales and Actinomycetales showed that cell wall composition was certainly a factor to be considered as a taxonomic character, and that our results on DAP distribution in whole cells were exactly paralleled by theirs on walls. In 1957, I suggested that there was a common "basal structure" in walls of Eubacteriales, Actinomycetales and blue-green algae (Work 1957). This structure included the two hexosamines glucosamine and muramic acid, and glutamic acid, alanine and only one diamino acid, either DAP or lysine. The arrangement 
of these components was then unknown, but I suggested that the peptides linked to the hexosamine chains were either cross-linked or cyclic because of the bifunctional nature of the diaminopimelic acid. The same amino acids were also known to be present in the nucleotide peptide which accumulated in penicillin-grown cells; this nucleotide was assumed to be a cell wall precursor accumulating because the penicillin prevented synthesis of cell walls (Park and Strominger 1957).

How far have we come in the 12 years since the origin of the idea of a common basal structure? There certainly is a common basal structure, now known as mucopeptide, glycopeptide, peptidoglycan or murein (it will be called mucopeptide here). The structure has been described in this Symposium by Tipper (1970). Diamino acids do take part in cross linking, but their number (Table 1) is greater than the two (DAP or lysine, never both) originally described, and more than one type or isomer may be present in the same organism. Thus the picture has become more complicated with increase in knowledge, but certain taxonomic features have emerged.

Table 1. Diamino acids of bacterial cell walls.<smiles>[R]C(N)CCCC(N)C(=O)O</smiles>

\begin{tabular}{|c|c|c|c|}
\hline Amino acid & $\mathbf{n}$ & $\mathrm{R}$ & Distribution* \\
\hline $\begin{array}{l}\text { L-lysine } \\
\text { D-lysine }\end{array}$ & $\{3$ & $\mathrm{H}$ & $\begin{array}{l}\text { Wide } \\
\text { Very limited }\end{array}$ \\
\hline $\begin{array}{l}\text { L-ornithine } \\
\text { D-ornithine }\end{array}$ & )$^{2}$ & $\mathrm{H}$ & $\begin{array}{l}\text { Limited } \\
\text { Very limited }\end{array}$ \\
\hline $\begin{array}{l}\text { L-diaminobutyric } \\
\text { D-diaminobutyric }\end{array}$ & $\{1$ & $\mathrm{H}$ & $\begin{array}{l}\text { Very limited } \\
\text { Very limited }\end{array}$ \\
\hline $\begin{array}{l}\text { meso-Diamonopimelic } \\
\text { LL-diaminopimelic } \\
\text { DD-diaminopimelic }\end{array}$ & $\left\{\begin{array}{l}3 \\
3\end{array}\right.$ & $\mathrm{COOH}$ & $\begin{array}{l}\text { Very wide } \\
\text { Limited } \\
\text { Very limited }\end{array}$ \\
\hline$\beta$-hydroxy-diaminopimelic & 3 & $\mathrm{COOH}$ & Limited \\
\hline
\end{tabular}

* See Tables 2 and 3 for details.

It was not until 1964 that the list of wall diamino acids was extended to include the lower homologues of lysine. Ornithine was found in Micrococcus radiodurans (Work 1964; Work and Griffiths 1968), in species of plant pathogenic corynebacteria (Perkins and Cummins 1964) and in some lactobacilli and related species (Veerkamp et al. 1965; Kandler 1967). Diaminobutyric acid was reported in other plant pathogenic Corynebacterium species (Perkins and Cummins 1964). The $\beta-\mathrm{OH}$ derivative of $\overline{\mathrm{DAP}}(2,6$-diamino-3-hydroxypimelic acid), isolated by Perkins (1965) from walls of Ampulariella regularis, had been demonstrated by paper chromatography ("slow spot") by Hoare and Work (1957), Yamaguchi (1965) and Szaniszlo and Gooder (1967) in various members of Actinomycetales. 
Since mucopeptides invariably contain D-glutamic acid and D-alanine, it was perhaps not surprising that the $\mathrm{D}$-isomers of diamino acids are also present in some species. Thus, the most common diamino acid is the meso (internally compensated) form of DAP, with one asymmetric centre in the $D$-configuration and the other in the $L$-configuration. The two other isomers of DAP (LL and DD), although less widely distributed, are present in various species (Hoare and Work 1955, 1957; Cummins and Harris 1958; Yamaguchi 1965; Szaniszlo and Gooder 1967). D-ornithine has been found in walls of certain species of plant pathogenic Corynebacterium and a few other organisms (Perkins and Cummins 1964; DucNguyen and Weed 1964; Kandler, private communication; Guinand et al. 1969), while the presence of both $L_{-}$and D-diaminobutyric acid in mucopeptides of Corynebacterium insidiosum and $C$. sepedonicum has been demonstrated (Perkins 1968). Recently, D-lysine has been identified in Butyribacterium rettgeri (Guinand et al. 1969). However, as will be discussed later (Table 3), the main tetra-peptide chain containing D-glutamic acid and D-analine does not usually have the two other amino acids in the $\mathrm{D}$-configuration, so the $\mathrm{D}$-diamino acids are still very interesting taxonomic features.

Some aspects of the distribution of diamino acids in walls of various species is shown in Table 2. L-lysine is found in walls of nearly all species of Gram-positive cocci, in most species of Lactobacillus and in many species of Arthrobacter. It is also present in Actinomyces bovis and in Corynebacterium pyogenes, an exceptional species of Corynebacterium. An unusual organism is Bacillus sphaericus where lysine is present in walls of vegetative cells, but not of spores which contain DAP.

The most widely distributed diamino acid is meso-DAP, which has been found in all Gram-negative organisms so far investigated (Review, Martin 1966), also in most species of marine bacteria, although the extreme halophiles (Halobacterium) lack mucopeptides (Larsen 1967). It is present in most species of Bacillus, Clostridium, Corynebacterium and Mycobacterium; also in Lactobacillus plantarum, and in some exceptional species of Micrococcus and Propionibacterium (Hoare and Work 1957; Cummins and Harris 1958). Organisms related to bacteria, such as bluegreen algae, Myxobacteriales, rickettsias and spirochetes are also found to contain meso-DAP as the main diamino acid, with lesser amounts of one or both the other isomers (Cummins and Harris 1958; Cummins 1962; Becker et al. 1965; Lechevalier 1970); some species of Micromonospora, Actinoplanes, Ampulariella may also have $\beta-O H-D A P$ in addition.

Identification of meso-DAP is usually carried out by a chromatographic technique which only separates the LL-isomer from the meso- and DDforms (Rhuland et al. 1955). Results obtained in this way only indicate that either or both $\overline{m e s o-}$ and DD-isomers are present. Certain identification of the meso-isomer may be carried out by the use of stereospecific enzymes which do not attack the DD-isomer (Hoare and Work 1957). Alternately, isolation of the DAP or one of its derivatives and measurement of optical rotation can be employed, as for Corynebacterium diphtheriae and Mycobacterium tuberculosis (Work 19 $\overline{51 \text { ), Aerobacter }}$ cloacae (Jusic et al. 1964) and E. coli (Diringer and Jusic 1966). Isolation of dinitrophenyl-DAP from enzymic digests of walls of Bacillus megaterium KM gave the surprising result that the mucopeptide contained $85 \%$ meso and 15\%-DD DAP (Briscas et al. 1967). Absence of DD-DAP cannot, therefore, be taken for granted without rigid proof. DD-DAP was 


\begin{tabular}{|c|c|c|c|c|c|c|c|}
\hline \multicolumn{2}{|c|}{ D1aminopimelic } & $\mathrm{B}-\mathrm{OH}-\mathrm{Dap}$. & I-lysine & \multicolumn{2}{|c|}{ ornithine } & $\underline{x s}+0 x m$ & Diaminobutyric \\
\hline $\begin{array}{l}\text { All Gram-negative } \\
\text { Bacillus } \\
\text { B.megaterium } \\
\text { Clostridium } \\
\text { Corynebacterium } \\
\text { L.plantarum } \\
\text { li. variana } \\
\text { M.citreus } \\
\text { P.shermanil } \\
\text { P.freudenreiohil }\end{array}$ & $\begin{array}{l}\text { Cl.perfringens } \\
\text { Cl.fermentans } \\
\text { Cl.pectinovorum } \\
\text { Propionibacter- } \\
\text { ium } \\
\text { Arthrobacter }\end{array}$ & & $\begin{array}{l}\text { Hicrococcus } \\
\text { Staphylo- } \\
\text { coceus } \\
\text { Sarcina } \\
\text { Steptococcus } \\
\text { Pediococcus } \\
\text { Leuconostoo } \\
\text { Iactobacillus } \\
\text { o . pyogenes } \\
\text { Arthrobecter }\end{array}$ & $\begin{array}{l}\text { Micrococous } \\
\text { radiodurans } \\
\text { J. bifidus } \\
\text { Bifidobacterium }\end{array}$ & $\begin{array}{l}\text { Brevibacterium } \\
\text { c.poinsettiae } \\
\text { C. betae } \\
\text { C.flacumfaciens } \\
\text { Arthrobacter }\end{array}$ & Bifidabacterium & $\begin{array}{l}\text { c.insidiosum } \\
\text { c.tritici } \\
\text { c.sepedonicum }\end{array}$ \\
\hline 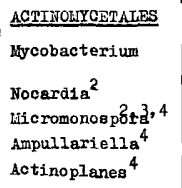 & Streptomyces 5 & $\begin{array}{l}\text { Ampullariel15 } \\
\text { Actinoplanes }\end{array}$ & A.bovis & & & $\begin{array}{l}\text { A.israel11 } \\
\text { A.nneslund11 }\end{array}$ & \\
\hline $\begin{array}{l}\text { OOAER ORGANISUS } \\
\text { Cyanophyta } \\
\text { (blue preen } \\
\text { algae) } \\
\text { Myrobacteriales } \\
\text { Rickettrieae } \\
\text { Spirochaetaceae } \\
\text { aaiobacterium }\end{array}$ & & & \multicolumn{5}{|c|}{ 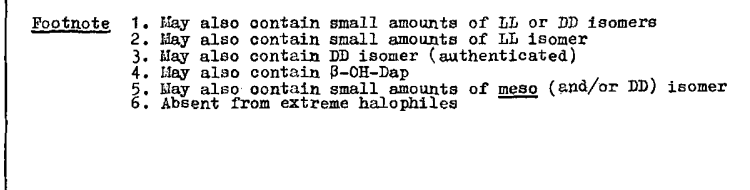 } \\
\hline
\end{tabular}




\begin{tabular}{|c|c|c|c|c|c|c|c|c|c|}
\hline \multirow[t]{2}{*}{ Example } & \multirow[t]{2}{*}{ Organism } & \multirow[t]{2}{*}{ Reference } & \multicolumn{2}{|c|}{ Amino acid } & \multicolumn{3}{|c|}{ Diamino acids } & \multicolumn{2}{|c|}{ Cross-link } \\
\hline & & & $A^{\mathrm{a}}$ & $B^{a}$ & Name & Location $^{b}$ & 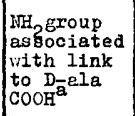 & Type & $\begin{array}{l}\text { Bridge } \\
\text { amino acids } \\
\text { at } x\end{array}$ \\
\hline I & Escherichia coli & 1 & Iralanine & Diamino acja & meso-Dap & $\mathrm{x}^{\mathrm{c}}$ & $\mathrm{NHH}_{2}(D)^{\mathrm{C}}$ & $D$ & 0 \\
\hline II & Bacillus megaterium, $\mathrm{KuA}$ & 1 & $"$ & $"$ & meso-Dap & $\mathrm{K}^{\mathrm{c}, \mathrm{d}}$ & $\mathrm{NH}_{2}{ }^{2}(D)^{\mathrm{C}}$ & D & 0 \\
\hline III & Lactobacillus plantarum & 2 & $n$ & " & meso-Dap & if & - & D & 0 \\
\hline IV & Propionibacterium vetersonii & 3 & Iralanine & Diamino acid & LI-Dap & III & $\mathrm{NH}_{2}(\mathrm{~L})$ & D & gly \\
\hline $\mathrm{V}$ & Clostridium pexfringens & 3 & $"$ & $"$ & LI-Dap & II & $\mathrm{NH}_{2}(\mathrm{~L})$ & D & gly \\
\hline VI & Streptomyces roseochromogens & 4 & " & $"$ & LL-Dap & ii. & $\sin _{2}^{2}(\mathrm{I})$ & D & gly \\
\hline VII & Lactobacillus casei & 5 & I-alanine & Diamino acid & L-lys & ii & $e^{2}$ & D & D-asp \\
\hline VIII & Llicrococcus lysodeikticus & 6 & " & " & $L-1$ ys & if $\&: x$ & $c$ and $a$ & D & $\begin{array}{l}\text { D-ala. L-lys. } \\
\text { D-Glu.L-ala }\end{array}$ \\
\hline IX & Streptococcus faecalis & 7 & $n$ & $"$ & In-lys & III & $\varepsilon$ & D & $(t-3 i a)_{3}$ \\
\hline$x$ & llicrococcus radiodurans & 8 & L-alanine & Diamino acid & I-orn & ii & $\delta$ & D & gly 3 \\
\hline $\mathrm{XI}$ & Lactobacillus cellobiosus & 9 & $n$ & $"$ & L-orn & in & $\delta$ & D & D-asp \\
\hline XII & Bir̂idobacter bifidum & 10 & " & $"$ & L-orn & H & 6 & D & D-asp.I-ser \\
\hline ZIII & Bifidobacter adolescentis & 10 & I-alanine & Diamino acid & $\begin{array}{l}\text { I-orn } \\
\text { Im-lys }\end{array}$ & us & $\delta$ and 2 & D & D-asp \\
\hline $\mathrm{XIV}$ & Corynebacterium pointsettiae & 11 & glycine & $\begin{array}{l}\text { L-Homo- } \\
\text { serine }\end{array}$ & D-orn & $\mathrm{x}$ & $a$ & G & D-orn \\
\hline$x y$ & Corynebacterium barkeri & 10 & Elycine & $\begin{array}{l}\text { L-Homo- } \\
\text { serine }\end{array}$ & D-orn & $\mathrm{x}$ & $a$ & G & giy.D-orn \\
\hline $\mathrm{XVI}$ & Brevibacterium imperiale & 10 & Elycine & $\begin{array}{l}\text { L-Horno- } \\
\text { serine }\end{array}$ & I-lys & $\mathrm{x}$ & $\varepsilon$ & G & $\operatorname{gIy}_{2} \cdot L-1 \mathrm{ys}$ \\
\hline XVII & licrobacterium lacticum & 12 & glycine & Irlys & L-lys & $x \&$ I.I & 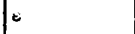 & G & gly.I-1ys \\
\hline XVIII & Corynebacterium insidiosum & 10 & zlycine & $L-I a b^{f}$ & $\begin{array}{l}L-D a b^{f} \\
D-D a b\end{array}$ & $x \& \mathrm{H}$ & $\alpha$ & G & $D-D a b^{f}$ \\
\hline $\mathrm{xIX}$ & Butyribacterium retgerii & 13 & I-serine & L-orn & $\left\{\begin{array}{l}\text { L-orn+ } \\
\text { D-orn+ } \\
\text { D-lys }\end{array}\right.$ & $x \& 1$. & $\alpha$ & G & $\begin{array}{l}\text { D-orn } \\
\text { D-lys }\end{array}$ \\
\hline
\end{tabular}




\section{Footnotes for Table 3.}

a Cross-link type D

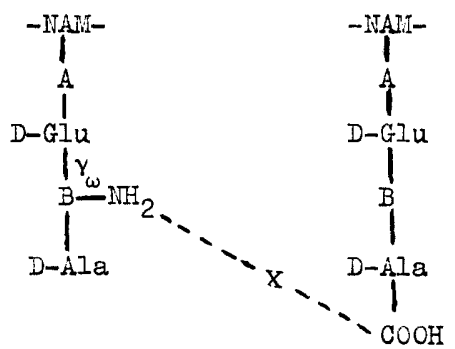

a Cross-link type $G$

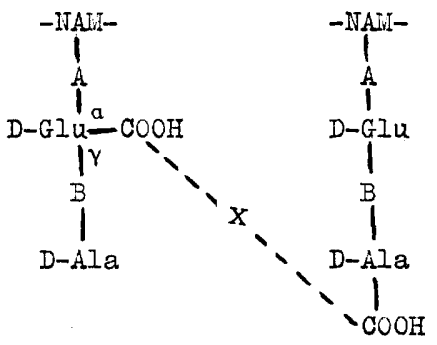

b. $M=$ Main chain, $K=$ cross link

c. 'L-end' in main chain 'D-end' in cross link

d. DD-isomer also present, position unknown

e. In different polymer units

f. Dab a diaminobutyric acid

\section{References}

1. van Heijenoort et al. 1969.

2. Matsuda et al. $\overline{19} \overline{68}$, Weis et al. 1967.

3. Schleifer et àl. 1968a.

4. Arimara $\overline{\text { et }} \overline{\mathrm{al}}$. 1968 .

5. Kandler $\overline{19} 6 \overline{7}$.

6. Schleifer and Kandler 1967a.

7. Schleifer and Kandler $1967 \mathrm{~b}$.

8. Ghuysen 1968 , cited.

9. Plapp and Kandler 1967.

10. Kandler, private communication.

11. Perkins 1967.

12. Schleifer et a1. $1968 \mathrm{~b}$.

13. Guinard et al. 1969.

14. Perkins $\overline{1} 9 \overline{68}$.

identified by combination of paper chromatography and enzymic digestion in 3 strains of Micromonospora (Hoare and Work 1957), but no other investigations on its occurrence in other species have been reported.

LL-DAP is easily identified by paper chromatography, and is the only diamino acid present in most species of Propionibacterium, in Clostridium perfringens and $\mathrm{Cl}$. fermentens and in certain species of Streptomyces (Hoare and Work 1957; Allsop and Work 1963; Cummins and Harris 1958; Cummins 1962). It is interesting to note that Salton (1957) recorded minor amounts of LL-DAP in addition to the meso-isomer in walls of B-megaterium KM, although this was not reported by Bricas et al. (1967).

In general, walls of Actinomycetales have been found to contain mixtures of diamino acids more frequently than those of other types of organism. For example, major or minor amounts of 2 or 3 isomers of DAP, and also $\beta$-OH-DAP can occur (Hoare and Work 1957; Yamaguchi 1965; Szanislo and Gooder 1967; Cummins 1962), while Actinomyces is raelii contains both lysine and ornithine (Cummins 1965). 
L-Ornithine may be found among L. bifidus and certain Bifidobacterium and in Micrococcus radiodurans; $D$-ornithine or diaminobutyric acid $\overline{\text { are }}$ present in species of plant pathogenic Corynebacterium (Perkins and Cummins 1964).

It should be noted that the DAP plays a dual role in many bacterial cells, it is a precursor of lysine as well as a wall constituent (Meadow and Work 1959). LL-DAP is converted to lysine by an epimerase (formerly called racemase) which produces the meso-isomer; this isomer is converted to L-lysine through the decarboxylase (White, Lejeune and Work 1969; Dewey, Hoare and Work 1954). In the nutritionally-exacting species of Lactobacillaceae, lysine is not synthesised and neither DAP nor the enzymes metabolising it are present; in the less exacting Micrococcaceae, DAP is usually absent from walls, but one or both of the enzymes are present (Antia, Hoare and Work 1957). Ornithine also has a dual role, as it is a precursor of arginine.

The amino acid sequences in the peptide portions of mucopeptide molecules have been worked out in certain cases. Table 3 gives a summary of the roles played by the diamino acids in the known types of sequences. Mucopeptides may be divided into 2 types according to the site of termination of the cross link (X) from the D-alanine-COOH of an adjacent chain (see Table 3, footnote). In type D cross link, (e. g. I-XIII), the amino acid $\mathrm{B}$ in the main tetra-peptide chain (between the $\omega-\mathrm{NH}_{2}$ of diamino acid and the $-\mathrm{NH}_{2}$ of terminal $\mathrm{D}$-alanine) is the diamino acid, and the cross link terminates at the side chain $\omega-\mathrm{NH}_{2}$ group of $\mathrm{B}$. Type G cross link (e.g. XIV-XIX) terminates at the a-COOH of D-glutamic acid which is joined to $\mathrm{D}$-alanine by a diamino acid in position $\mathrm{X}$. In the less common type $G$ mucopeptides, the bifunctional natures of both the glutamic acid and the diamino acid are thus utilized for cross-linking. In type $D$ usually only a diamino acid in position $B$ is concerned in the cross link, and the a-COOH group of glutamic acid is frequently blocked by an amide or glycine residue. In type G mucopeptides, amino acid B is not necessarily a diamino acid but can be homoserine (e.g. XIV-XVI) and it never plays a part in cross-linking. An interesting organism of Type G is C. insidiosum (e.g. XVIII) where amino acid B (L-diaminobutyric acid) is thought to have its $\omega-\mathrm{NH}_{2}$ group masked by acetylation (Perkins 1968), perhaps being thus prevented from cross linking. It is not yet known if this type of blockage occurs in other species. The amino acid $A$ linked to muramic acid is invariably L-alanine in type B mucopeptides, and is either glycine or L-serine in type G mucopeptides.

The cross-link $X$ often contains one or more amino acids bridging the two main peptide chains; however, when meso-DAP is the diamino acid, the cross-link is often direct to $D$-alanine with no amino acids in the bridge (e.g. I-III). LL-DAP probably always has a glycine bridge attached to it (e.g. IV, V, VI), and in certain species of Actinomycetales which contain meso-DAP, glycine is also found in the acid hydrolysates of walls, on which no sequence work has yet been done (Yamaguchi 1965; Becker at al. 1965; Lechevalier 1969). When other L-diamino acids are in position $\bar{B}$, the bridges are usually $\mathrm{D}$-iso-asparagine or one or more short-chain neutral amino acids (the exceptions being certain Micrococcus species, e.g. VIII).

In E. coli and B. megaterium (e.g. I and II) the $-\mathrm{NH}_{2}$ group of DAP conce $\bar{r}$ ne in the cross link is located on the D-asymmetric carbon, while the $-\mathrm{NH}_{2}$ group attached to the L-asymmetric carbon is in the main pep- 
tide chain between D-glutamic acid and D-alanine (Diringer and Jusic 1966; Bricas et al. 1967). Since other diamino acids known to be in position $B$ are $L-i$ atoms in alternating $L$ and $D$ configurations. D-Diamino acids appear to occur only in the type G cross-link.

When there are several bridge amino acids, it might appear to be difficult to decide which peptide chain is the "main" one and which is the bridge of the cross link. The main chain is that which is synthesised first in the precursor uridine diphosphonucleotide muramyl pentapeptide (A. D-glu. B. D-ala. D-ala); the bridge amino acids are attached to this at a later stage and the cross-link is completed finally with elimination of a D-alanine residue (Strominger et al. 1967). Nucleotide peptide precursors accumulate in bacterial cells grown in the presence of certain antibiotics such as penicillin, cycloserine or vancomycin and can be isolated. Examination of the peptide portions of these nucleotides will establish the nature and sequence of the "main chain" amino acids (Perkins 1967, 1968; Miller et al. 1968).

In type $G$ mucopeptides, the diamino acid in the cross link may be the $D$ - or the L-isomer, and the sequence of the bonds depends on their configurations. Thus (e.g., XIV, XV), D-ornithine is bound to the $-\mathrm{COOH}$ of $\mathrm{D}$-alanine through its $\mathrm{a}-(\mathrm{D})-\mathrm{NH}_{2}$ group, the $\omega-\mathrm{NH}_{2}$ group being joined to a-COOH of D-glutamic acid, either directly or through glycine. With L-lysine in the cross-link (e.g., XV, SVI) it is the $\omega-\mathrm{NH}_{2}$ which is connected to $D$-alanine while the $a-(L)-\mathrm{NH}_{2}$ is joined to the $a-C O O H$ of $D$ glutamic acid (through glycine in one case). Certain organisms (XVIII and XIX) contain both isomers of diamino acids, in these cases the Lisomers are in the main chain, and the $\mathrm{D}$-isomers are in the cross link. Example XIX contains both D-lysine and D-ornithine which appear to be in different polymer units: here each a-(D) $-\mathrm{NH}_{2}$ group is connected to $\mathrm{D}-$ alanine and the $\omega-\mathrm{NH}_{2}$ group is joined to $\mathrm{D}$-glutamic acid.

From the few examples cited here and in other papers in this Symposium, it appears that neither carboxyl group of glutamic acid can combine with an amino group attached to a carbon atom in the D-configuration, while the carboxyl of $\mathrm{D}$-alanine can combine with an amino group attached to a carbon atom in either the $\mathrm{D}$ - or the $\mathrm{L}$ configuration. Thus, the stereochemical requirement for peptide bond formation on the a-carboxy 1 group of D-glutamic acid may be stricter than that of the $\mathrm{D}$-alanine carboxyl group. These considerations, as well as many other unknown factors, probably affect the distribution of the various diamino acids among bacterial species.

\section{REF ERENCES}

Allsop, J. and E. Work. 1964. Biochem. J. 87:512.

Antia, M., D.S. Hoare and E. Work. 1957. Biochem. J. 65:448. Arimara, K., T. Nakamura and G. Tamura. 1968. Agr. Biol. Chem. 32:530.

Becker, H., M. P. Lechevalier and H. A. Lechevalier. 1965. Appl. Microbiol. 13:236.

Bricas, E., J. M. Ghuysen and P. Dezélée. 1967. Biochemistry $\underline{6}: 2598$. Cummins, C.S. 1962. J. Gen. Microbiol. 28:35. - 1965. Nature, London 206:1272. and H. Harris. 1956. J. Gen. Microbiol. 14:583. and 1958 . J. Gen. Microbiol. 18:173. 
Dewey, D. L., D.S. Hoare and E. Work. 1954. Biochem. J. 58:523.

Diringer, H. and D. Jusic. 1966. Z. Naturforsch. 21b:603.

Duc-Nguyen, H. and L. L. Weed. 1964. J. Biol. Chem. 239:3372.

Ghuysen, J.M. 1968. Bact. Rev. 32:425.

Guinand, M., J.M. Ghuysen, K.H. Schleifer, and O. Kandler. 1969. Biochemistry 8:200.

Heijenoort, J. va $\vec{n}$, L. Elbas, P. Dezélée, J.F. Petit, E. Bricas and J. M. Ghuysen. 1969. Biochemistry 8:207.

Hoare, D.S. and E. Work. 1955. Biochem. J. 61:562. and - 1957. Biochem. J. 65:441.

Jusic, D, C. Roy and R. W. Watson. 1964. Canad. J. Biochem. 42:1553. Kandler, O. 1967. Ztbl. Bakt. Abt. Orig. 205:197.

Larsen, H. 1967. Advances in Microbial Physiology; 1:97. Edit. A.H. Rose and J.F. Wilkinson, London. Academic Press.

Lechevalier, H.A. 1970. This symposium.

Martin, H. H. 1966. Ann. Rev. Biochem. 35:457.

Matsuda, T., S. Kotani and E. Kato. 1968. Biken J. 11:111,127.

Meadow, P. and E. Work. 1959. Biochem. J. 72:400.

Miller, I., R. Plapp and O. Kandler, 1968. Z. Naturforsch. 23(b):217.

Park, J. T. and J. L. Strominger. 1957. Science 125:99.

Perkins, H. R. 1965. Nature, London 208:872. . 1967. Biochem. J. 102:29C. - 1968. Biochem. J. $\overline{110: 47 P .}$ and C.S. Cummins. 1964. Nature, London 201:1105.

Plapp, R. and O. Kandler. 1967. Biochem. Biophys. res. com. 28:141. Rhuland, L. E., E. Work, R. F. Denman and D.S. Hoare. 1955. J.

Amer. Chem. Soc. 77:4844.

Salton, M.R. J. 1953. Biochim. Biophys. Acta 10:512. . 1957. Nature, London 180:338.

Schleifer, K. H. and O. Kandler. 1967a. Biochem. Biophys. res. Com. 28:156. and 1967b. Archiv. für Microbiol. 57:335.

, R. Plapp and O. Kandler. 1968a. F. E. B. S. Letters $1: 287$. and $1968 \mathrm{~b}$. Biochim. Biophys. Acta 154:573.

Strominger, J. L. , K. Izaki, M. Matsuhashi and D. J. Tipper. 1967. Fed. Proc. 26:9.

Szanisklo, P.J. and H. Gooder. 1967. J. Bact. 94:2037.

Tipper, D.J. (1970). This symposium.

Veerkamp, J.H., R. Lambert and Y. Saito, 1965. Arch. Biochem. Biophys. 112:120.

Weiss, N., R. Plapp and O. Kandler. 1967. Archiv. für Mikrobiol. 58:313.

White, P.J., B. Lejeune and E. Work. 1969. Biochem. J. 113:589.

Work, E. 1951. Biochem. J. 49:17. - 1957. Nature, London 179:841. - 1964. Nature, London $\overline{201}: 1107$. and D. L. Dewey. 1953. J. Gen. Microbiol. 9:394. and H. Griffiths. 1968. J. Bact. 95:641.

Yamaguchi, T. 1965. J. Bact. 89:444. 
